\title{
Impact of Applied Nitrogen Concentration on Growth of Elatior Begonia and New Guinea Impatiens and Susceptibility of Begonia to Botrytis cinerea
}

\author{
Dharmalingam S. Pitchay \\ Department of Biological Sciences, University of Toledo, Mail Stop 601, 2801 West Bancroft, \\ Toledo, OH 43606 \\ Jonathan M. Frantz ${ }^{1}$ and James C. Locke \\ USDA-ARS-ATRU, University of Toledo, Mail Stop 604, 2801 West Bancroft, Toledo, OH 43606 \\ Charles R. Krause \\ USDA-ARS-ATRU, 1680 Madison Avenue, Wooster, OH 44691
}

George C. J. Fernandez

University of Nevada, Nevada Agricultural Experiment Station/204, Reno, NV 89557-0105

\begin{abstract}
AdDitional INDEX wORDs. plant nutrition, floriculture, biotic stress
Abstract. Plant performance and appearance in deficient and toxic levels of nutrients are well characterized. However, less is known about the potential subtleties of plant growth, form, development, nutrient uptake, and biotic stress tolerance in the broad tolerable range. Begonia [Beg (Begonia $\times$ tuberhybrida Voss)] and new guinea impatiens [NGI (Impatiens hawkeri Bull.)] were grown over a wide range of $\mathrm{N}$ (from 1.78 to $57.1 \mathrm{~mm} \mathrm{NH}_{4}: \mathrm{NO}_{3}$ ratio at a 1:1 ratio supplied as nutrient solution) in a peat:perlite soilless substrate in greenhouse conditions. Plant growth, development, chlorophyll content, leaf angle, nutrient uptake, tissue caloric value, and susceptibility to Botrytis cinerea Pers.:Fr. disease were evaluated in two experiments. Elevated $\mathrm{N}$ supply resulted in decreased plant height $(16 \%$ in Beg and $7 \%$ to $16 \%$ in NGI), flower count (3\% to $48 \%$ in Beg and $7 \%$ to $49 \%$ in NGI), bud numbers (23\% to $80 \%$ in Beg), canopy area (11\% to $33 \%$ in NGI), and mass (21\% to $33 \%$ in Beg and $18 \%$ to $58 \%$ in NGI). Chlorophyll content saturated at an $\mathrm{N}$ supply of $28.6 \mathrm{~mm}$. $\mathrm{N}$ uptake efficiency, shoot $\mathrm{N}$ use efficiency, and shoot $\mathrm{N}$ utilization efficiency decreased with increasing $\mathrm{N}$ supply. Elevated levels of $\mathrm{N}$ supply from 7.15 to $\mathbf{5 7 . 1} \mathrm{mm}$ also increased the susceptibility of Beg to B. cinerea disease by $10 \%$ to $80 \%$ in stems and $3 \%$ to $14 \%$ in leaves. The increase in susceptibility also corresponded with increased tissue energy content $\left(\mathrm{kJ}^{\mathrm{g}} \mathrm{g}^{-1}\right)$ and altered leaf orientation. This study indicates many plant changes occur between nutrient extremes that can have a significant impact on growth, development, and the ability to withstand disease.
\end{abstract}

Nitrogen uptake by plants is generally in anionic $\left(\mathrm{NO}_{3}^{-}\right)$, cationic $\left(\mathrm{NH}_{4}{ }^{+}\right)$, or neutral $\left(\mathrm{CH}_{4} \mathrm{~N}_{2} \mathrm{O}\right)$ forms. Excessive addition of a single element may cause an imbalance of other nutrients (Marshner, 1995; Mengel and Kirkby, 2001; Mills and Jones, 1996) and may predispose plants to disease (Engelhard, 1989; Hoffland et al., 2000; Huber and Watson, 1974; Jarvis, 1992; Mansfield, 1980; Marshner, 1995). The probability of $\mathrm{N}$ toxicity is rare because unlike micronutrients, a toxic $\mathrm{N}$ concentration is several-hundred-fold higher than sufficient $\mathrm{N}$ concentrations. However, the practice of periodic fertigation (fertilizer mixed with irrigation water) of concentrations substantially higher than published recommendations is not

Received for publication 5 May 2006. Accepted for publication 28 Sept. 2006. We thank Tera McDowell, Sarah Lancianese, Stephen Ohene-Larbi, and Chetan Chautary for their assistance throughout the studies; the Paul Ecke Ranch and Oglevee for providing the plant material; Smithers-Oasis for providing propagation medium; and members of the Toledo Area Flower and Vegetable Growers Association for their helpful guidance.

Mention of a trademark, proprietary product, or vendor does not constitute a guarantee or warranty of the product by the USDA and does not imply its approval to the exclusion of other products or vendors that also may be suitable. ${ }^{1}$ Corresponding author. E-mail: Jonathan.Frantz@utoledo.edu. uncommon under intensive greenhouse production systems. The $\mathrm{N}$ use efficiency is critical in determining $\mathrm{N}$ supply rate, which ultimately can reduce input costs while protecting the environment from $\mathrm{N}$ deposition (Good et al., 2004). In greenhouse production systems, especially under soilless culture, plant $\mathrm{N}$ uptake is solely dependant on external supply. Objective assessment of $\mathrm{N}$ use efficiency will provide vital information for the greenhouse industry, which leads to prudent management of resources.

Much of the literature on plant nutrition focuses on plant growth effects in the nutritional extremes of either toxicity or deficiency. There are fewer evaluations of the sometimes subtle changes in plant growth and appearance and the potential for increased plant pathogen susceptibility in commonly encountered N concentrations (Kent and Reed, 1996; Nelson et al., 1978; Smith et al., 1998).

Studies have linked N supply and disease (David et al., 2003; Engelhard, 1989; Huber and Watson, 1974; Mengel and Kirby, 2001). High N supply has resulted in increased disease susceptibility to Pseudomonas syringae van Hall pv. tomato (Okabe) Young, Dye \& Wilkie and Oidium lycopersicum Cook \& Mass. for tomato (Lycopersicum lycopersicum L.) (Hoffland 
et al., 2000) in contrast with resistance to $B$. cinerea with high $\mathrm{N}$ supply in tomato (Hoffland et al., 1999). This inconsistency could be the result of the type of pathogens, $\mathrm{N}$ form, source and concentration, type of substrate, irrigation frequency, and growing environment. Commercially blended fertilizers that contain high concentrations of $\mathrm{NH}_{4}{ }^{+}$are lower in $\mathrm{Ca}$ (Nelson, 1996). High levels of $\mathrm{Ca}$ and $\mathrm{K}$ have significant influence on disease resistance (Elad and Volpin, 1993; Marshner, 1995; Mengel and Kirby, 2001). Calcium has a major physiological role in forming the cell membrane and cell wall, which protects against pathogens (Elad, 1988; Elad and Evensen, 1995; Volpin and Elad, 1991). High potassium also suppresses disease in plants (Mengel and Kirby, 2001; Talbot and Zeiger, 1996). These confounding findings could be a potential factor for conflicting reports of the influence of $\mathrm{N}$ in disease-related studies.

Botrytis cinerea is a ubiquitous pathogen that infects leaves, stems, and flowers. Symptoms of the disease appear as watersoaked lesion spots, which quickly coalesce affecting the entire tissue, causing major economic loss (Elad, 1988; Hausbeck and Moorman, 1996). Susceptibility to $B$. cinerea disease has been reported to decrease with $\mathrm{NO}_{3}^{-}$form but increase with $\mathrm{NH}_{4}{ }^{+}$ form (Huber and Watson, 1974). Conversely, it has also been reported that $B$. cinerea shows no growth benefit based on the form of $\mathrm{N}$ supplied to the plant (Townsend, 1957).

Begonia [Beg (Begonia $\times$ tuberhybrida Voss)] and new guinea inpatiens [NGI (Impatiens hawkeri Bull.)] are categorized as high-valued plants grown in pots and hanging baskets (U.S. Dept. Agr., 2005). These plants are succulent with tender tissues and are considered inefficient in terms of water use, requiring ample water supply but not water-logged conditions (Hartley, 1995). This creates a moist growing environment causing the plants to be susceptible to the ubiquitous fungal pathogen $B$. cinerea (Elad and Shtienberg, 1995; Hausbeck and Moorman, 1996). The nutritional requirement is moderate for these species (Nelson, 2005). All these factors contributed to the selection of these greenhouse plants as model species for biotic stress and nutritional interaction studies.

This study was conducted to investigate the growth of Beg and NGI, N uptake efficiency, shoot $\mathrm{N}$ use efficiency, and shoot $\mathrm{N}$ utilization efficiency and the potential susceptibility of these plants to biotic stress (disease: $B$. cinerea) to $\mathrm{N}$ concentrations that are commonly found in commercial greenhouses. This study provides insight about the nutritional economy of plants across a range of $\mathrm{N}$ supply.

\section{Materials and Methods}

Two experiments were conducted in a glass greenhouse set at night/cloudy day/clear day temperatures of $17 / 21 / 24{ }^{\circ} \mathrm{C}$ with relative humidity ranging from $20 \%$ to $50 \%$. In Expt. 1, NGI cv. Pure Beauty Purple was grown from 22 Jan. 2004 to 5 Apr. 2004, and in Expt. 2, Beg cv. Barbara was grown from 7 Apr. 2004 to 1 June 2004. Photoperiod was maintained at $16 \mathrm{~h}$ using a 1 lamp:1 lamp ratio of high-pressure sodium and metal halide lamps. Minimum light levels were $200 \mu \mathrm{mol} \cdot \mathrm{m}^{-2} \cdot \mathrm{s}^{-1}$ (under electric lamps) and as high as $800 \mu \mathrm{mol} \cdot \mathrm{m}^{-2} \cdot \mathrm{s}^{-1}$ during sunny days measured with a single quantum sensor (model QSO; Apogee Instruments, Logan, Utah) located in the center of the greenhouse. In both experiments, rooted cuttings were transplanted into $15-\mathrm{cm}$ diameter pots containing $70 \%$ sphagnum peatmoss, 30\% horticultural grade perlite (by volume) amended with dolomitic limestone $\left(3.0 \mathrm{mg} \cdot \mathrm{L}^{-1}\right)$, and a micronutrient $\mathrm{mix}$ (0.59 $\mathrm{mg} \cdot \mathrm{L}^{-1}, 12 \% \mathrm{Fe}, 2.5 \% \mathrm{Mn}, 1.0 \% \mathrm{Zn}, 0.5 \% \mathrm{Zn}, 0.1 \% \mathrm{~B}$, and $0.05 \%$ Mo by mass, Micromax; Scott's Co., Marysville, Ohio). The newly transplanted cuttings were watered with reverse osmosis water once and then fertilized with $3.6 \mathrm{~mm}$ $\mathrm{N}$ concentration of $20 \mathrm{~N}-8.8 \mathrm{P}-16.6 \mathrm{~K}$ fertilizer $(0.5 \% \mathrm{Mg}$, $0.0068 \%$ B, $0.0036 \% \mathrm{Cu}, 0.05 \% \mathrm{Fe}, 0.025 \% \mathrm{Mn}, 0.0009 \%$ Mo, $0.0025 \%$ Zn; Scott's Co.) during the initial 2 weeks of cutting establishment before treatments. Treatment nutrient solution pHs were adjusted to 5.8 using $\mathrm{Ca}(\mathrm{OH})_{2}$ and $\mathrm{H}_{2} \mathrm{SO}_{4}$ as required. The plants were irrigated to runoff and received at least a $15 \%$ leachate fraction (estimated) to reduce the risk of continuous salt buildup resulting from the fertilizer treatments. Plants were harvested during the seventh and eighth weeks of treatment for Beg and NGI, respectively. Some of the Beg plants were set aside at that time to study their susceptibility to $B$. cinerea.

In Expt. 1, the treatments consisted of six $\mathrm{N}$ levels, 1.78, $3.57,7.15,14.3,28.6$, and $42.86 \mathrm{~mm} \mathrm{~N}$ as $\mathrm{NH}_{4} \mathrm{NO}_{3}$ in the nutrient solution. Expt. 2 consisted of the same $\mathrm{N}$ treatments plus $57.1 \mathrm{~mm} \mathrm{~N}$ in the same form. The remainder of the nutrient solutions consisted of millimolar concentrations of $0.67 \mathrm{PO}_{4}-\mathrm{P}$, $1.67 \mathrm{~K}, 2.3 \mathrm{Ca}, 1.3 \mathrm{Mg}$, and $1.3 \mathrm{SO}_{4}-\mathrm{S}$ plus micromolar concentrations of $71 \mathrm{Fe}, 9 \mathrm{Mn}, 1.5 \mathrm{Cu}, 1.5 \mathrm{Zn}, 45 \mathrm{~B}, 0.1 \mathrm{Mo}, 4.6 \mathrm{Cl}$, and $0.2 \mathrm{Na}$ using $\mathrm{KH}_{2} \mathrm{PO}_{4}, \mathrm{MgSO}_{4}, \mathrm{~K}$-EDTA, $\mathrm{CaCl}_{2}$, Fe-DTPA, $\mathrm{MnCl}_{2}, \mathrm{CuCl}_{2}, \mathrm{ZnCl}_{2}, \mathrm{H}_{3} \mathrm{BO}_{3}$, and $\mathrm{Na}_{2} \cdot 2 \mathrm{MoO}_{4}$. The solutions used deionized water of 18 Mohm purity. The mean electrical conductivity (EC) of the treatment nutrient solutions with $1.78,3.57,7.15,14.3,28.6,42.86$, and $57.1 \mathrm{~mm} \mathrm{~N}$ were $1.5,1.8,2.2,2.8,3.3,4.3$, and $4.8 \mathrm{mS} \cdot \mathrm{cm}^{-1}$, respectively. The experiments were laid out in randomized complete block designs with six (Expt. 1) or seven (Expt. 2) treatments and five replications with three plants per experimental replicate.

Growth Measurements. In both experiments, the plants were photographed and analyzed for canopy coverage using image analysis software (Assess; American Phytopathological Society, St. Paul, Minn.). Percent maximum canopy coverage of leaf canopy area was calculated by dividing the total number of pixels of each treatment by the highest pixel treatment. Leaf orientation angle was determined by superimposing a protractor, in software, to a plant's side view and measuring three to four mature or maturing leaves from three replicate plants in each treatment. At the end of the growth period, plant height was measured from the base of the stem to the top of the plant, flower and bud number were counted, and then harvested by cutting the stem of the plant at the top of the soilless medium. Shoots were dried in a forced air drying oven at $70{ }^{\circ} \mathrm{C}$ for at least $2 \mathrm{~d}$ and dry weight was recorded. There were no apparent differences in the starting size of the plants for height, mass, spread, and leaf angles.

PH AND ELECTRICAL CONDUCTIVITY MEASUREMENTS. Substrate $\mathrm{pH}$ and EC values were measured using the pour-through method (Wright, 1986), whereby $50 \mathrm{~mL}$ of leachate was collected from each pot by adding $150 \mathrm{~mL}$ of deionized water on the surface of the substrate; an additional $20 \mathrm{~mL}$ to $30 \mathrm{~mL}$ of water was added if there was insufficient leachate as a result of dryness of the substrate. The $\mathrm{pH}$ and $\mathrm{EC}$ values were measured from the collected leachate using electric probes (models Inlab 730 and 413; Mettler Toledo, Columbus, Ohio) and a meter (model SevenMulti; Mettler Toledo). 
Chlorophyll measurement. Chlorophyll content was estimated nondestructively using a portable chlorophyll meter (SPAD-502; Minolta Camera Co., Ltd., Tokyo). Four readings per plant were taken on the adaxial surface of recently matured leaves.

Energy measurement. Caloric values were measured according to the method described by Long (1934) and Yang et al. (2003). Oven-dried ground tissue samples of $1 \mathrm{~g}$ or less were used. A known amount of mineral oil was added to the sample as a binding agent and pressed into a pellet with a press (Parr Instrument Co., Moline, Ill.). The pellets were then combusted in a bomb calorimeter (Parr 6200; Parr Instrument Co.). Because mineral oil burns with the plant sample, the effect of mineral oil combustion must be corrected by multiplying mineral oil energy content by mineral oil amount in each sample and subtracting that value from the total energetic value. The difference is the energetic content of the sample. The total shoot caloric value of a plant was calculated by multiplying the caloric value per gram of tissue by total shoot dry weight.

Tissue Analysis. Recently matured leaf samples were washed in $0.1 \mathrm{~N} \mathrm{HCl}$ for $30 \mathrm{~s}$ and rinsed in deionized water for $30 \mathrm{~s}$. The samples were oven-dried at $70{ }^{\circ} \mathrm{C}$ for at least $2 \mathrm{~d}$ and ground in a mortar and pestle. The tissue was analyzed for macroand micronutrients with the exception of $\mathrm{N}$ using inductively coupled plasma emission spectrophotometry (model IRIS Intrepid II; Thermo Electron Corp., Waltham, Mass.). Total $\mathrm{N}$ was analyzed using a C-H-N analyzer (Carlo Erba NA 1500 Nitrogen Analyzer; Thermo Electron Corp.).

Botrytis CINEREA INOCUlation. Botrytis cinerea was cultured on potato dextrose agar plates (DIFCO, Sparks, Md.) at $25{ }^{\circ} \mathrm{C}$ for $7 \mathrm{~d}$ to $10 \mathrm{~d}$ until it produced abundant conidia. The plates were flooded with reverse osmosis water and conidia dislodged with a glass rod. The conidial suspension was adjusted to $2.5 \times 10^{5}$ conidia $/ \mathrm{mL}$ using a hemacytometer and sprayed onto plants to runoff. Beg plants were inoculated during the eighth week at the time other plants were harvested and measured for growth. Figure 1 shows the approximate plant sizes of each treatment. The inoculated plants were kept in a plastic-covered tunnel that maintained at least $80 \%$ relative humidity using a humidifier. The inoculated plants were incubated for $10 \mathrm{~d}$. On day 10 after inoculation, the plants were scored for black to gray necrotic lesions on the leaf lamina and stems.
Nitrogen UPTAKE EFFICIENCY. Each efficiency parameter was defined previously by Goins et al. (2004) and Good et al. (2004). N uptake efficiency (tissue $\mathrm{N}$ concentration $\times$ shoot dry weight/ $\mathrm{N}$ supply) is a measure of total $\mathrm{N}$ taken up and accumulated by the plant in relation to the total $\mathrm{N}$ supplied. Shoot $\mathrm{N}$ use efficiency [(shoot dry weight/ $\mathrm{N}$ supply $) \times 100]$ measures the change in shoot dry weight per unit of $\mathrm{N}$ supplied to the plant. Shoot $\mathrm{N}$ utilization efficiency [(shoot dry weight/ total $\mathrm{N}$ content $) \times 100$ ] measures the efficiency of $\mathrm{N}$ partitioning to the shoot.

Statistical anAlysis. All the data were subjected to analysis of variance using PROC GLM SAS (SAS Institute, Cary, N.C.). Where the F test indicated a significant $(P \leq 0.05)$ treatment effect, differences among the treatment means were computed by LSMEANS and compared by the least significant difference 0.05 method. Regression analysis was done to assess 
linear and quadratic effects using Sigma Plot (version 6.0; Jandel Scientific, San Rafael, Calif.).

\section{Results}

Plant growth. Plant height peaked at $7.15 \mathrm{~mm} \mathrm{~N}$ and decreased at higher $\mathrm{N}$ rates for Beg (Figs. 1A, 2). The reduction in plant height was more gradual and linear in NGI with a height difference of $13.6 \%$ between the lowest and the highest $\mathrm{N}$ supply. In Beg, the highest $\mathrm{N}$ treatment resulted in shoots that were comparable in size to the lowest $\mathrm{N}$ treatment but $\approx 3 \mathrm{~cm}$ or $15 \%$ shorter than the $7.15 \mathrm{~mm} \mathrm{~N}$ treatment. The number of flowers or buds was highest in both species at low $\mathrm{N}$ supply (1.78 to $7.15 \mathrm{~mm} \mathrm{~N}$; Fig. 1B) and declined (3\% to $48 \%$ in Beg and $7 \%$ to $49 \%$ in NGI) as $\mathrm{N}$ supply increased above $14.3 \mathrm{~mm}$.

There was also a peak in shoot dry weight at $7.15 \mathrm{~mm} \mathrm{~N}$ (Fig. 1C), but additional $\mathrm{N}$ supply resulted in decreased shoot dry weight $(21 \%$ to $33 \%$ in Beg and $18 \%$ to $58 \%$ in NGI). The lowest shoot dry weight was produced at highest $\mathrm{N}$ level of 42.86 and $57.1 \mathrm{~mm}$ in NGI and Beg, respectively. The shoot dry weight produced at the lowest $\mathrm{N}$ was greater than at the highest $\mathrm{N}$ for both species.

Leaf orientation also changed with different $\mathrm{N}$ supply rates. Leaf orientation was more upright at the lowest $\mathrm{N}$ concentration and less upright as the $\mathrm{N}$ concentration increased (Figs. 1D and E, 3A-D). The leaf angle decreased as $\mathrm{N}$ supply increased within different leaf age groups in both species. Leaf orientation in both species was almost horizontal, less than $20^{\circ}$ and $10^{\circ}$ for maturing leaves and matured leaves, respectively. Leaf angle was greater in young and maturing leaves for both crops with $\mathrm{N}$ levels less than $14.7 \mathrm{~mm}$. This was best seen in Beg plants by looking at the uppermost (young, expanding) leaves. When viewed from above the plant, many leaf edges can be seen in plants receiving low $\mathrm{N}$ concentrations, whereas in high $\mathrm{N}$ concentrations, full leaves arranged parallel to the growing surface could be seen (Fig. 3A and B). For NGI, the leaf angle is best seen from the side as leaves of all ages were droopy and curled when fed with increasing $\mathrm{N}$ concentrations (Fig. 2). in NGI.
Chlorophyll content, based on SPAD readings, increased for both Beg and NGI with higher N (Table 1). Chlorophyll content reached a maximum at 28.6 and $42.86 \mathrm{~mm} \mathrm{~N}$ for NGI and Beg, respectively. NGI leaf canopy area was greatest at $7.15 \mathrm{~mm} \mathrm{~N}$ and decreased significantly at higher N (Table 1). Maturing and recently matured leaves of NGI developed necrosis resembling $\mathrm{K}$ deficiency or $\mathrm{NH}_{4}^{+}$toxicity along the margins from the
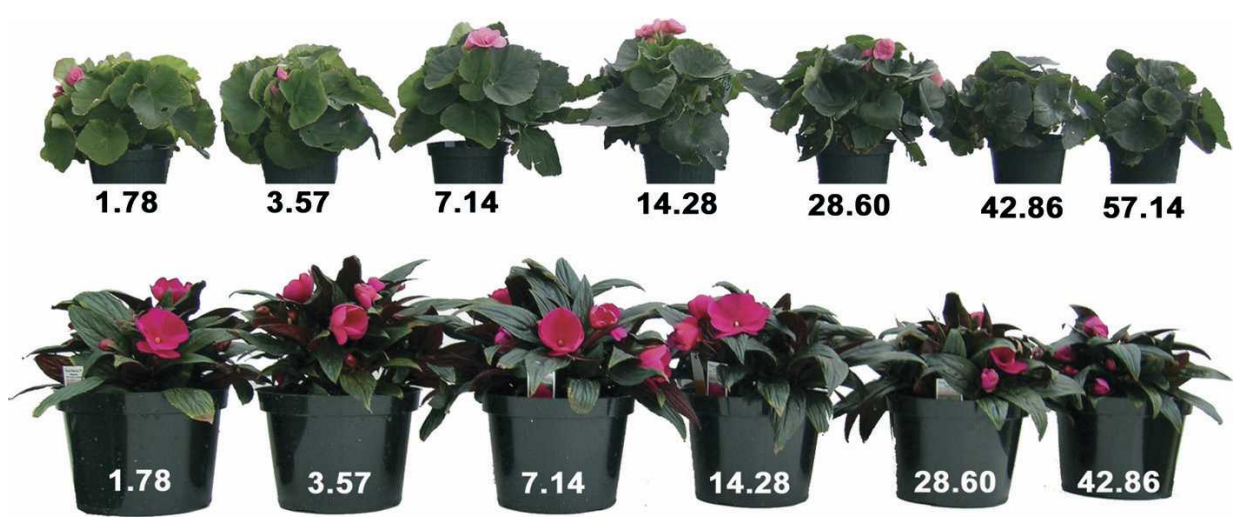

Fig. 2. Side views of begonia [Beg (top)] and new guinea impatiens [NGI (bottom)] receiving different amounts of $\mathrm{N}$. Numbers at the bottom of each pot is the $\mathrm{N}$ concentration supplied in mM.
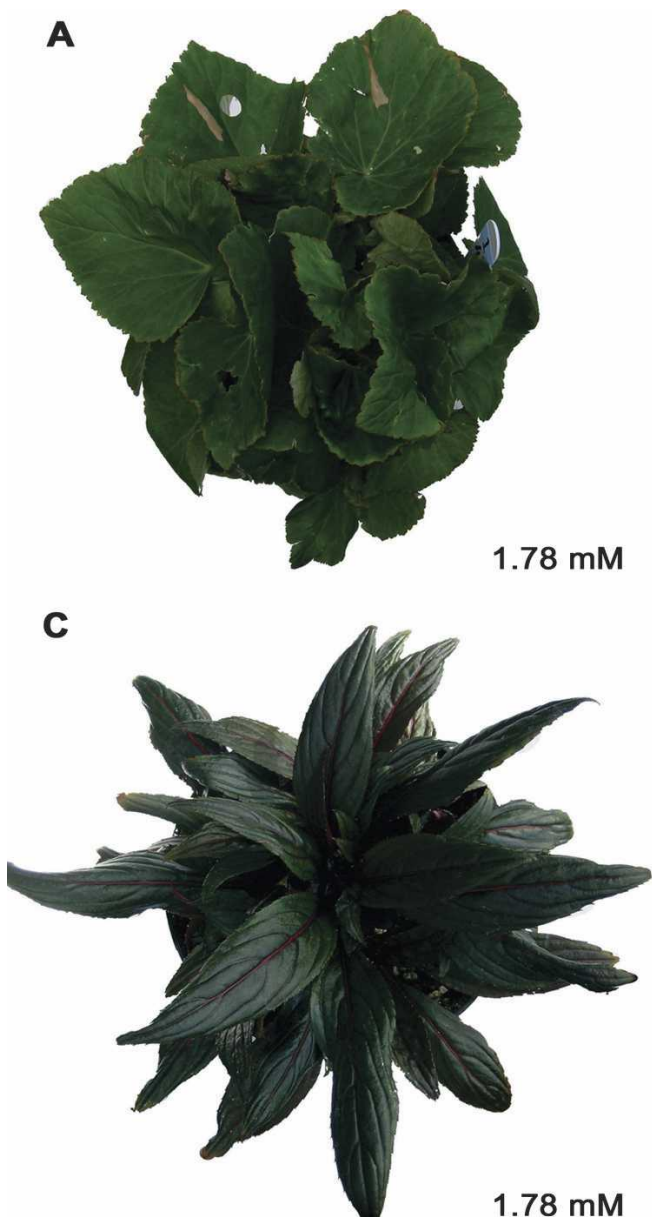

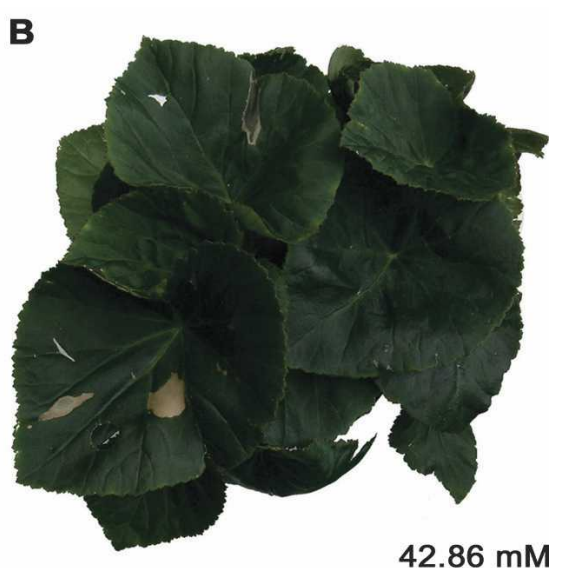

D

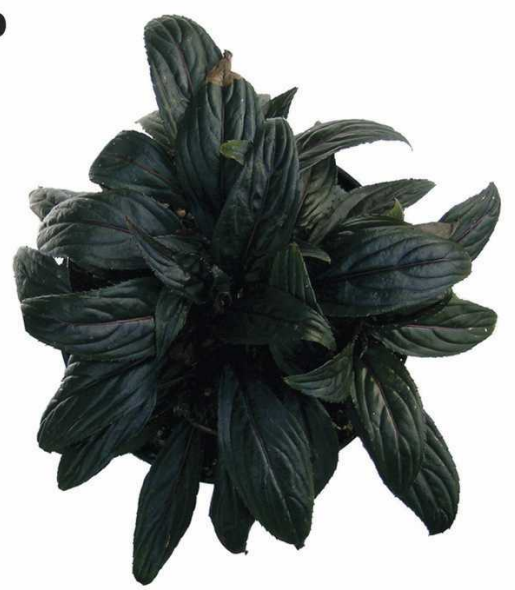

$42.86 \mathrm{mM}$

Fig. 3. Top view of begonia (Beg) receiving (A) $1.78 \mathrm{~mm} \mathrm{~N}$ and (B) $42.86 \mathrm{~mm}$ N or new guinea impatiens (NGI) receiving $(\mathbf{C}) 1.78 \mathrm{~mm} \mathrm{~N}$ or $(\mathbf{D}) 42.86 \mathrm{~mm} \mathrm{~N}$. Leaves receiving high $\mathrm{N}$ are less erect than those receiving high $\mathrm{N}$ as evidenced by more of the Beg whole leaves being visible and parallel to the planting surface or droopy leaves 
Table 1. Correlation between N supply and chlorophyll content as indicated by SPAD value and percent maximum canopy coverage in begonia (Beg) and new guinea impatiens (NGI).

\begin{tabular}{lccc}
\hline Treatment & \multicolumn{2}{c}{ SPAD value } & \multirow{2}{*}{$\begin{array}{c}\text { Maximum canopy } \\
\text { coverage }(\%) \text { NGI }\end{array}$} \\
\cline { 2 - 3 } N supplied (mM) & Beg & NGI & 92.4 \\
\hline 1.78 & 42.6 & 62.5 & 88.8 \\
3.57 & 49.5 & 69.5 & 100.0 \\
7.15 & 53.7 & 70.4 & 89.3 \\
14.3 & 56.9 & 76.3 & 84.2 \\
28.6 & 59.2 & 78.3 & 66.7 \\
42.86 & 62.6 & 76.9 & - \\
57.10 & 63.0 & - & $*$ \\
$P$ & $* *$ & $*$ & $*$ \\
Linear & $* *$ & $*$ & Ns \\
Quadratic & Ns & $*$ & 0.8859 \\
$r^{2}$ & 0.8547 & 0.9097 & \\
Ns,*,**Nonsignificant or significant at $P<0.05$ or 0.01, respectively.
\end{tabular}

terminal tip to the middle of the leaf lamina with $\mathrm{N} 28 \mathrm{~mm}$ or greater N. High N (greater than $28 \mathrm{~mm} \mathrm{~N}$ ) plants had poor root systems. Beg plants treated with high $\mathrm{N}$ developed black necrotic lesions at the stem base close to the substrate. Maturing and matured leaves of Beg treated with $1.78 \mathrm{~mm} \mathrm{~N}$ developed light chlorosis with reddish pigmented margins resembling visual symptoms of $\mathrm{N}$ deficiency (Sprague, 1964). These symptoms were not apparent in NGI, perhaps as a result of the use of a dark-leafed variety in this study.

Botrytis Cinerea: Begonia interaction. When Beg plants were inoculated with $B$. cinerea, disease severity increased. The low $\mathrm{N}$ supply treatments from 1.78 to $7.15 \mathrm{~mm} \mathrm{~N}$ had less than $5 \%$ infection on leaves and stems (Fig. 1F). Plants fertigated with $28.6 \mathrm{~mm} \mathrm{~N}$ and above had higher percentages of infection, especially on the stems. Stem lesions occurred at the basal portion of the plant, which caused the plants to collapse. In some instances, plant death followed rapid B. cinerea progression.

Nutrient INTERACTIONs. There was a negative quadratic correlation between $\mathrm{pH}$ and increasing $\mathrm{N}$ supply from the third to seventh weeks for both species (Fig. 4A). The fertilizer used in this study would decrease the $\mathrm{pH}$ if $\mathrm{NH}_{4}{ }^{+}$was preferentially taken up by the plant over $\mathrm{NO}_{3}{ }^{-}$. If this was the case, the resulting acidity would quickly neutralize the lime added to the media in our study. As a result of the nature of the fertilizer treatments, the EC also increased with higher $\mathrm{N}$ supply (Fig. 4B), which can also cause $\mathrm{pH}$ to drop. The EC of the fertilizer collected from pots was consistently lower for NGI than Beg. This difference may have been attributable in part to differences in nutrient uptake between the species. For each macronutrient, NGI contained more than Beg (Fig. 5A-E and results below), which would lead to less salts collected from the NGI pots.

Tissue $\mathrm{N}$ concentration increased quadratically with increasing $\mathrm{N}$ supply in both species (Fig. 5A). In NGI tissue, $\mathrm{N}$ concentrations were $2.6 \%$ and $7.5 \%$ at $\mathrm{N}$ concentrations of 1.78 and $42.86 \mathrm{~mm}$, respectively. In Beg, the tissue $\mathrm{N}$ concentrations were $2.0 \%$ and $5.5 \%$ with $\mathrm{N}$ concentrations of 1.78 and $57.1 \mathrm{~mm}$, respectively. In NGI, tissue P concentration increased to the highest value at $14.1 \mathrm{~mm} \mathrm{~N}$ (Fig. 5B) but decreased slightly at higher $\mathrm{N}$ concentrations. Tissue $\mathrm{P}$ increased linearly with increasing $\mathrm{N}$ for Beg. There was a significant linear

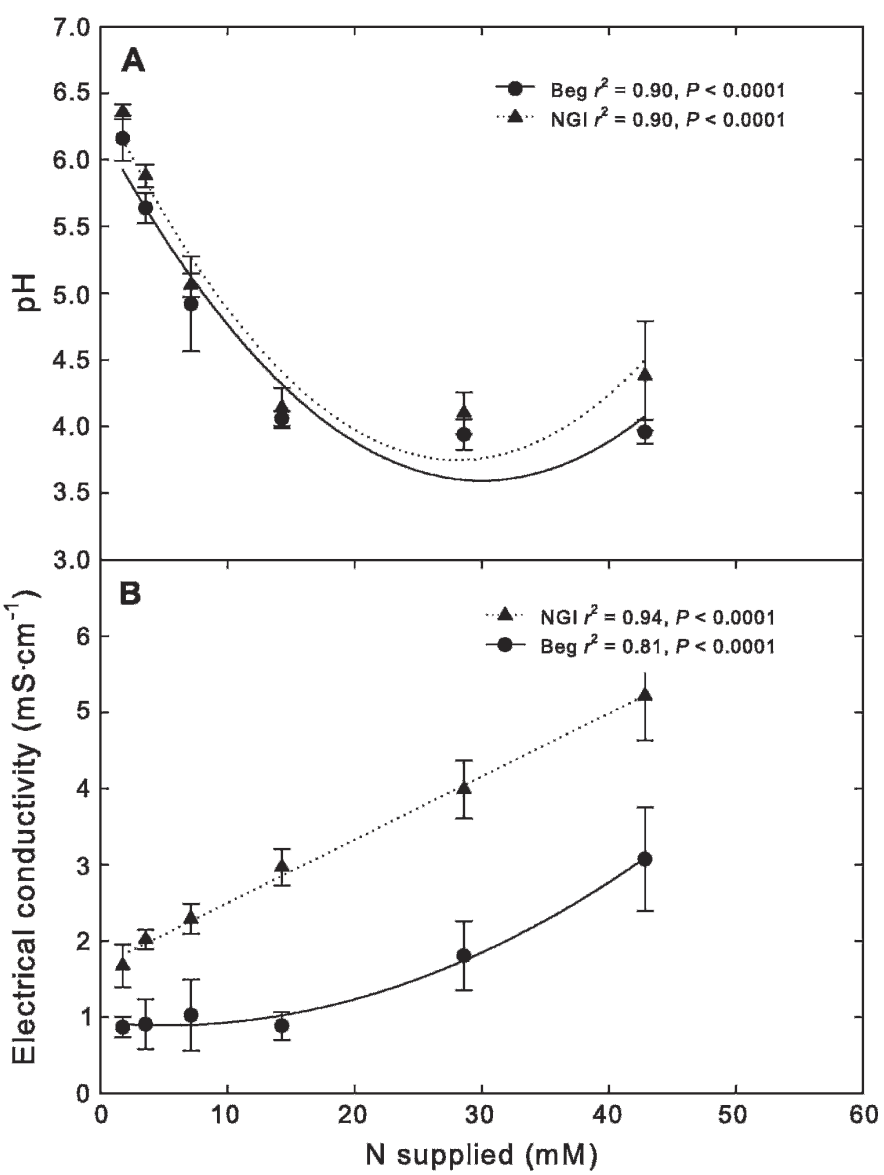

Fig. 4. $\mathrm{pH}$ and electrical conductivity (EC) of collected leachate from pots of the different $\mathrm{N}$ treatments of begonia (Beg) and new guinea impatiens (NGI). Regression models between $\mathrm{N}$ supply and $\mathrm{pH}$ values (A) in Beg $\mathrm{n}=29 ; \mathrm{y}=$ $6.23-0.18 \mathrm{x}+0.0029 \mathrm{x}^{2}$ and NGI $\mathrm{n}=29 ; \mathrm{y}=6.49-0.19 \mathrm{x}+0.0035 \mathrm{x}^{2}$, or EC values $(\mathbf{B})$ in Beg $\mathrm{n}=29 ; \mathrm{y}=0.93-0.016 \mathrm{x}+0.0015 \mathrm{x}^{2}$ and NGI $\mathrm{n}=29 ; \mathrm{y}=$ $1.62+0.092 \mathrm{x}-0.0002 \mathrm{x}^{2} . r^{2}$ values are presented when it is statistically significant at $P<0.05$. Error bars are \pm 1 standard deviation from the average.

decrease in $\mathrm{K}$ content with increased $\mathrm{N}$ supply in Beg (Fig. 5C). NGI tissue $\mathrm{Ca}$ was highest between 7.15 and 14.3 mm in NGI (Fig. 5D) and then declined. Beg tissue Ca increased quadratically with increasing $\mathrm{N}$ supply. Tissue $\mathrm{Mg}$ peaked at $7.15 \mathrm{~mm} \mathrm{~N}$ for both species (Fig. 5E). The shapes of the curves could be a function of many different conditions in the root zone. Saturation of uptake may be occurring with some nutrients; nutrient availability could reach equilibrium in midranges of $\mathrm{N}$ concentrations (along with the corresponding $\mathrm{EC}$ and $\mathrm{pH}$ changes), or antagonistic/protagonistic effects may be altered as $\mathrm{N}$ concentration and preference for different $\mathrm{N}$ forms changes.

Significant differences in tissue $\mathrm{Fe}, \mathrm{Mn}, \mathrm{Zn}, \mathrm{Cu}$, and $\mathrm{B}$ concentration were noted with increasing $\mathrm{N}$ supply for both species (Fig. 6A and B). With some elements, the statistical trend is hidden as a result of the scale on the y-axis, so the regression line, $\mathrm{r}^{2}$, and $P$ value are shown for clarity.

Tissue Energy value. Beg tissue energy content increased from $15.1 \mathrm{~kJ} \cdot \mathrm{g}^{-1}(1.78 \mathrm{~mm} \mathrm{~N})$ to $19.7 \mathrm{~kJ} \cdot \mathrm{g}^{-1}(57.1 \mathrm{~mm} \mathrm{~N})$. Total shoot energetic value peaked at $7.15 \mathrm{~mm} \mathrm{~N}$ [242 kJ.plant (Beg)] and dropped to $167 \mathrm{~kJ}$ (Beg) at $57.1 \mathrm{~mm} \mathrm{~N}$ (NGI) (Fig. 7B). No such statistically significant trend was measured for the NGI. 


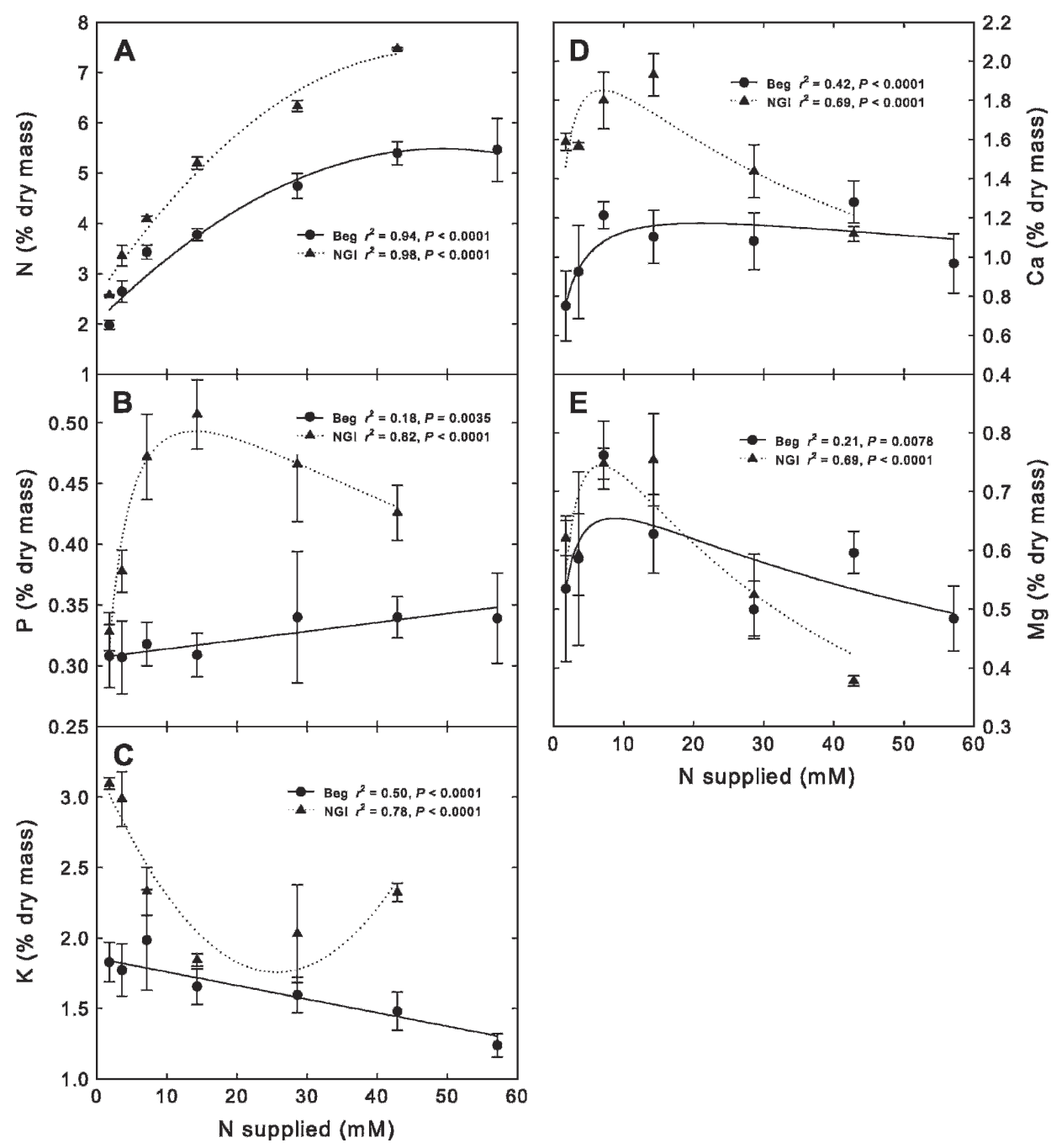

Fig. 5. The effect of $\mathrm{N}$ supply on macronutrient content of begonia (Beg) and new guinea impatiens (NGI) leaf tissue as a percentage of their dry weight. (A) $\mathrm{N}$ in Beg $\mathrm{n}=44 ; \mathrm{y}=2.04+0.14 \mathrm{x}-0.0014 \mathrm{x}^{2}$ and NGI $\mathrm{n}=17 ; \mathrm{y}=$ $2.54+0.20 \mathrm{x}-0.0021 \mathrm{x}^{2} ;$ (B) $\mathrm{P}$ in Beg $\mathrm{n}=44 ; \mathrm{y}=0.31+0.0007 \mathrm{x}$ and NGI $\mathrm{n}=17 ; \mathrm{y}=0.49 \mathrm{e}\{-0.5[\ln (\mathrm{x} / 13.99) /$ $\left.2.15]^{2}\right\} ;(\mathbf{C}) \mathrm{K}$ in Beg $\mathrm{y}=3.22-0.11 \mathrm{x}+0.0022 \mathrm{x}^{2}$ and NGI $\mathrm{n}=44 ; \mathrm{y}=1.85-0.0096 \mathrm{x} ;$ (D) Ca in Beg $\mathrm{n}=44 ; \mathrm{y}=$ $1.17 \mathrm{e}\left\{-0.5[\ln (\mathrm{x} / 20.97) / 2.65]^{2}\right\}$ and NGI $\mathrm{n}=17 ; \mathrm{y}=1.85 \mathrm{e}\left\{-0.5[\ln (\mathrm{x} / 6.94) / 1.98]^{2}\right\} ;(\mathbf{E}) \operatorname{Mg}$ in $\mathrm{Beg} \mathrm{n}=44 ; \mathrm{y}=$ $0.65 \mathrm{e}\left\{-0.5[\ln (\mathrm{x} / 8.73) / 2.49]^{2}\right\}$ and NGI $\mathrm{n}=17 ; \mathrm{y}=0.74 \mathrm{e}\left\{-0.5[\ln (\mathrm{x} / 6.74) / 1.73]^{2}\right\} . r^{2}$ values are presented when it is statistically significant at $P<0.05$. Error bars are \pm 1 standard deviation from the average.

$\mathrm{N}$ rates above this level delay development in these species as has been found in many other species (DíazPérez et al., 2003; Powell et al., 1988; Smith et al., 1998). Many direct and indirect effects could cause these growth differences.

Uptake of both forms of $\mathrm{N}$ is energy-dependent. $\mathrm{NO}_{3}{ }^{-}$is transported to the shoot and is either assimilated into amino acids and proteins or stored in vacuoles for future use. $\mathrm{NH}_{4}{ }^{+}$has to be converted into amino acids and proteins in the roots and transported to shoots (van Beusichem et al., 1988; von Wiren et al., 2000). Unassimilated $\mathrm{NH}_{4}^{+}$ cannot be stored and may be released as $\mathrm{NH}_{3}$, which is a toxic gas to cells and tissues (Britto et al., 2001a). The inability to store $\mathrm{NH}_{4}{ }^{+}$increases the demand for carbon skeletons, which reduces carbon availability for other functions in high $\mathrm{N}$ treatments. $\mathrm{NH}_{4}{ }^{+}$ disrupts biologic membranes, which interferes with redox gradient potential across membranes. Excessive $\mathrm{NH}_{4}{ }^{+}$uptake has also been reported to interfere with the water balance of the plants by restricting water flux from roots to shoots (Britto and Kronzucker, 2005; Britto et al., 2001a, 2001b). Both species took up large amounts of $\mathrm{NH}_{4}^{+}$as indicated by the decreasing $\mathrm{pH}$ (Fig. 4). This, along with reduced carbon availability, may have contributed to the necrotic margins in NGI. However, this damage could also have been the result of water stress attributable to high media EC levels.

The high $\mathrm{N}$ supply increased rhizosphere EC above the typical recommended normal range for Beg

Nitrogen uptake, USE, AND UTILIZATION EFFiCIENCY. The N uptake, use, and utilization efficiency decreased with increasing $\mathrm{N}$ for both species (Fig. 8A-C). $\mathrm{N}$ uptake was most efficient at $1.78 \mathrm{~mm} \mathrm{~N}$, but at $14.3 \mathrm{~mm} \mathrm{~N}$, shoot use efficiency was close to zero in both species. The shoot $\mathrm{N}$ use efficiency was lower than the $\mathrm{N}$ uptake efficiency by over $50 \%$ in lower $\mathrm{N}$ supply treatments. The shoot $\mathrm{N}$ use efficiency was greater in Beg than NGI from 1.78 to $7.15 \mathrm{~mm} \mathrm{~N}$ supply. At $14.3 \mathrm{~mm} \mathrm{~N}$ supply, shoot $\mathrm{N}$ use efficiency reached close to zero in both species. Shoot N utilization efficiency reached its lowest value of $\approx 20 \%$ for Beg and 15\% for NGI at or above $28.6 \mathrm{~mm} \mathrm{~N}$ supply.

\section{Discussion}

Plants supplied with $\mathrm{N}$ rates greater than $14.3 \mathrm{~mm} \mathrm{~N}$ were more compact, had darker green leaves, and fewer flower buds and flowers (Fig. 1) than plants at lower $\mathrm{N}$ rates indicating that and NGI (Fig. 4), and this may have resulted in additional negative effects on nutrient uptake (Epstein and Bloom, 2005; Marshner, 1995) and growth.

Nitrogen is the only element that exists in the environment in cationic and anionic forms, and $\mathrm{N}$ uptake will alter the rhizosphere $\mathrm{pH}$ potentially resulting in synergistic or antagonistic effect on uptake of other cations and anions (Hamlin et al., 1999; Kirby and Mengel, 1967; Magalhaes and Huber, 1989). $\mathrm{NH}_{4}{ }^{+}$supply may have suppressed $\mathrm{K}, \mathrm{Ca}$, and $\mathrm{Mg}$ uptake (Fig. 5), which resulted in low tissue concentrations of the respective elements in both species, although experimental levels are within critical guidelines for these species (Mills and Jones, 1996). However $P$, an anion, was above normal tissue $P$ concentration of $0.52 \%$ (Pitchay, 2002). The synergistic effect on $\mathrm{P}$ uptake was noted at $\mathrm{N}$ supply of 28.7 mmor less. However, the high EC and low buffering capacity of the substrate (Fig. 4; Harris et al., 1999; Osorio et al., 2003) may have resulted in decreased availability and uptake of competing nutrients. 


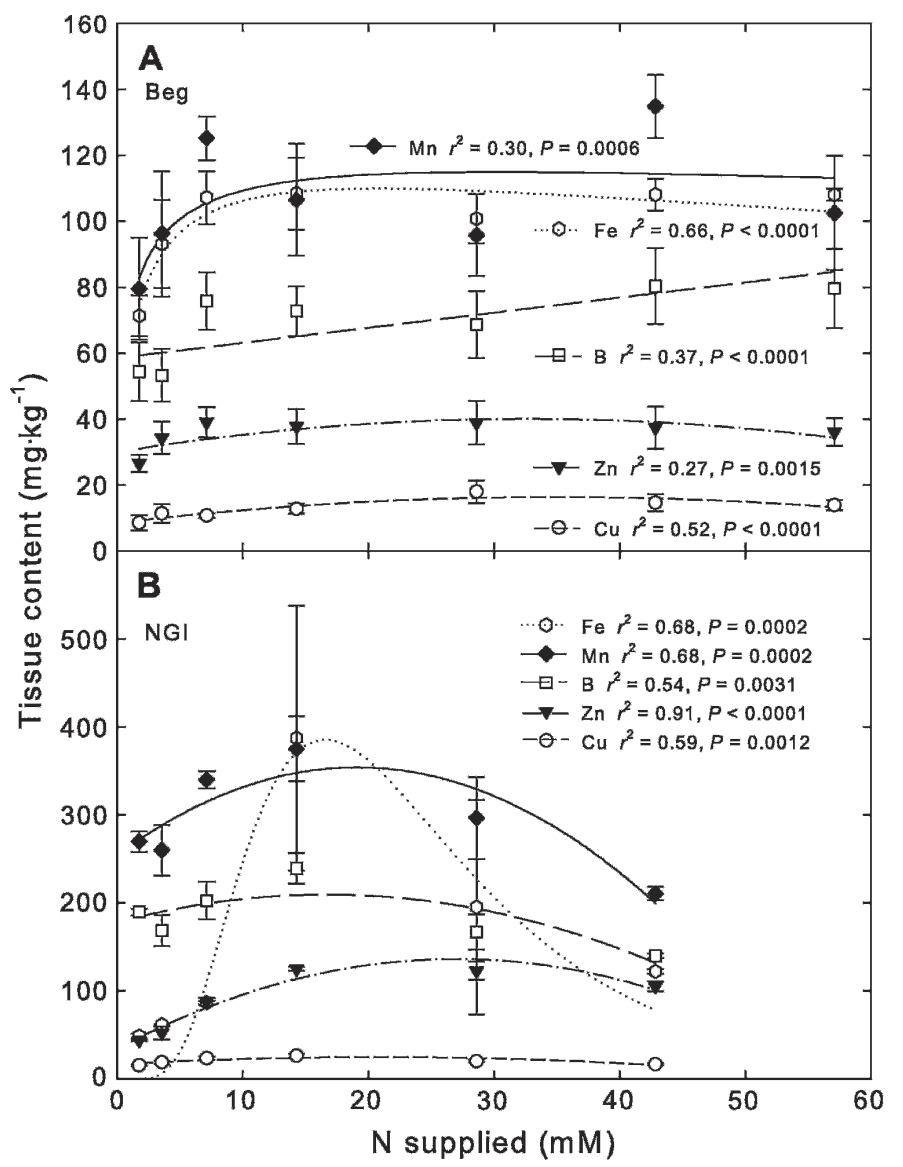

Fig. 6. The effect of $\mathrm{N}$ supply on micronutrient content of begonia (Beg) (A) and new guinea impatiens (NGI) (B) leaf tissue in $\mathrm{mg} \cdot \mathrm{kg}^{-1}$. For Beg, regression models $(\mathrm{n}=44)$ between $\mathrm{N}$ supply and Fe $\mathrm{y}=109.86 \mathrm{e}\{-0.5[\ln (\mathrm{x} / 20.80)$ $\left.2.79]^{2}\right\}, \operatorname{Mn} \mathrm{y}=114.90 \mathrm{e}\left\{-0.5[\ln (\mathrm{x} / 30.49) / 3.50]^{2}\right\}, \mathrm{B} \mathrm{y}=58.51+0.46 \mathrm{x}, \mathrm{Zn} \mathrm{y}=$ $30.01+0.61 \mathrm{x}-0.0095 \mathrm{x}^{2}$, and $\mathrm{Cu} \mathrm{y}=8.54+0.45 \mathrm{x}-0.0064 \mathrm{x}^{2}$. NGI regression models $(\mathrm{n}=17)$ between $\mathrm{N}$ supply and Fe $\mathrm{y}=385.15 \mathrm{e}\{-0.5[\ln (\mathrm{x} / 16.57) /$ $\left.0.53]^{2}\right\}$, Mn y $=254.21+10.45 \mathrm{x}-0.27 \mathrm{x}^{2}, \mathrm{~B} \mathrm{y}=177.89+3.78 \mathrm{x}-0.11 \mathrm{x}^{2}, \mathrm{Zn}$ $\mathrm{y}=33.83+7.58 \mathrm{x}-0.14 \mathrm{x}^{2}$, and $\mathrm{Cu} \mathrm{y}=16.46+0.80 \mathrm{x}-0.019 \mathrm{x}^{2}$ in NGI. $r^{2}$ values are presented when it is statistically significant at $P<0.05$. Error bars are \pm 1 standard deviation from the average.

High rates of $\mathrm{N}$ increased the number of plants infected with B. cinerea with high mortality occurring above $28.7 \mathrm{~mm} \mathrm{~N}$ (Fig. 1). Hoffland et al. (2000) reported similar findings in tomato, and David et al. (2003) reported the same pattern in powdery mildew (Erysiphe cichoracearum DC) infection in Beg. Several factors could have contributed to the increase in infection with increasing $\mathrm{N}$ supply treatments. The reduction in the shoot dry weight at supraoptimal $\mathrm{N}$ levels may have altered the $\mathrm{C}: \mathrm{N}$ ratio at the cellular level. Free amino acids and low-molecularweight nitrogenous compounds are good energy sources for pathogens (Hoffland et al., 1999). The preferential uptake of $\mathrm{NH}_{4}{ }^{+}$over $\mathrm{NO}_{3}{ }^{-}$, and antagonistic effect on $\mathrm{K}, \mathrm{Ca}$, and $\mathrm{Mg}$ uptake may have caused significant ionic imbalances affecting cell homeostasis (Britto and Kronzucker, 2005; Kirby and Mengel, 1967). The relatively low tissue concentration of $\mathrm{K}$ and $\mathrm{Ca}$ and the unbalanced $\mathrm{N}$ : $\mathrm{K}$ ratio in the nutrient solution as a result of increased $\mathrm{N}$ supply could have weakened the cell membrane and affected cell wall development (Stall, 1963; Volpin and Elad, 1991) resulting in less resistance to pathogen penetration of the cell walls. Damaged membranes could have also resulted in nutrient leakage that provided stimulation of

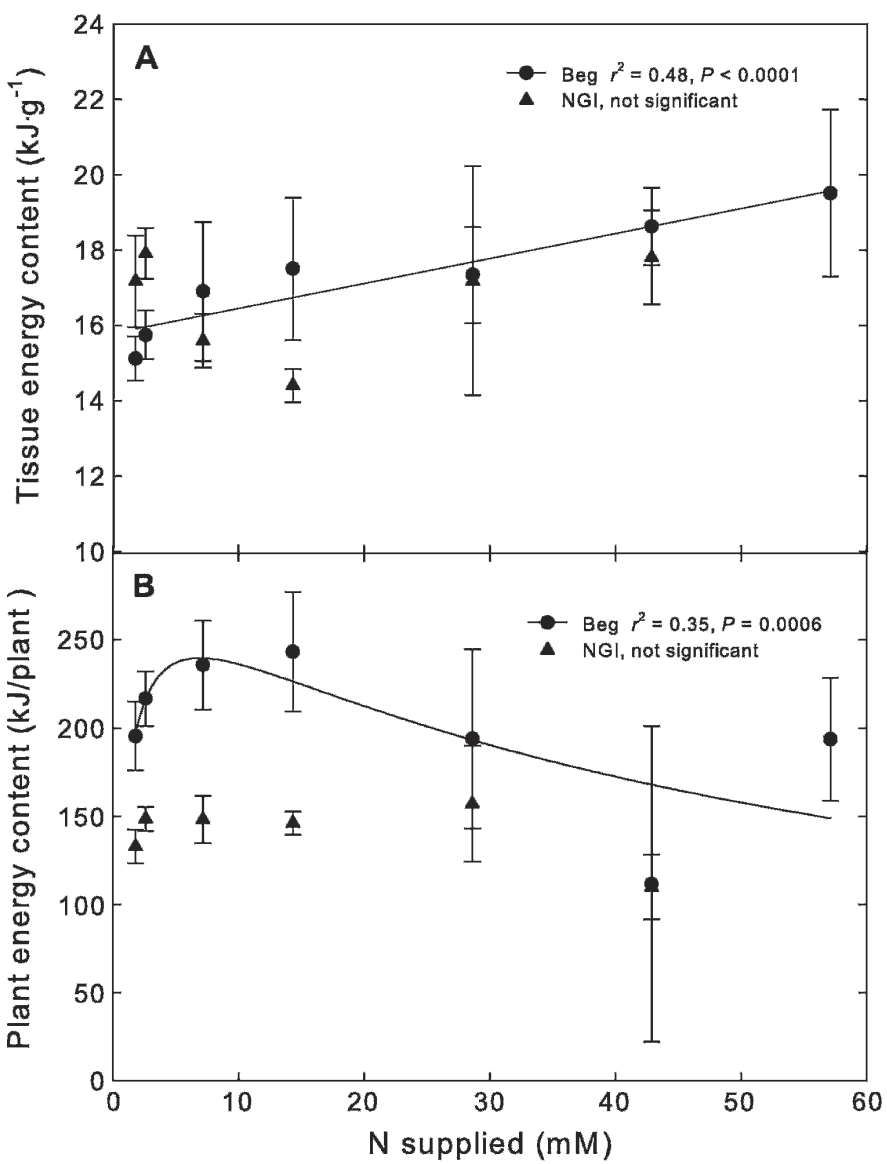

Fig. 7. Influence of $\mathrm{N}$ supply on tissue (A) and whole shoot (B) energy content for begonia (Beg) and new guinea impatiens (NGI). The regression model for Beg tissue energy content $\left(\mathrm{kJ} \cdot \mathrm{g}^{-1}\right) \mathrm{n}=36 ; \mathrm{y}=3749.06+16.81 \mathrm{x}$ and whole shoot energetic value (kJ.plant) $\mathrm{n}=36 ; \mathrm{y}=58,664.14 \mathrm{e}\{-0.5[\ln (\mathrm{x} / 6.81)$ $\left.1.82]^{2}\right\}$. Correlation was not significant for either parameter in NGI. $r^{2}$ values are presented when it is statistically significant at $P<0.05$. Error bars are \pm 1 standard deviation from the average.

B. cinerea infection (Harrison, 1988). The increase in tissue energy values of Beg plants supplied with elevated N (Fig. 7), indicating a nutrient-rich environment, increases the likelihood of successful colonization resulting from larger energy supplies per gram of biomass consumed by the pathogen. On the other hand, the low energy value of low N-supplied plants may have been an unfavorable environment for $B$. cinerea infection.

The change in the leaf angle and orientation with different levels of N supply, especially the leaf phylloplane (Fig. 1), may have provided a conducive environment for the pathogenic spores to land and attach themselves as an initial step of establishment (van Kan, 2005). This is followed by the anchoring and growing of the conidia as it uses the nutrients deposited on the leaves, which was more likely to be abundant in the horizontal phylloplane (as a result of residual deposition without runoff from leaves from overhead fertigation) as compared with more upright leaves.

Poor root systems in plants supplied with high $\mathrm{N}$ could have affected water uptake resulting in the substrate remaining moist for prolonged periods. This contributed to higher humidity microenvironments in these plants, especially near the lower portion of the plants, which are ideal for disease infection (Harrison, 1988). 


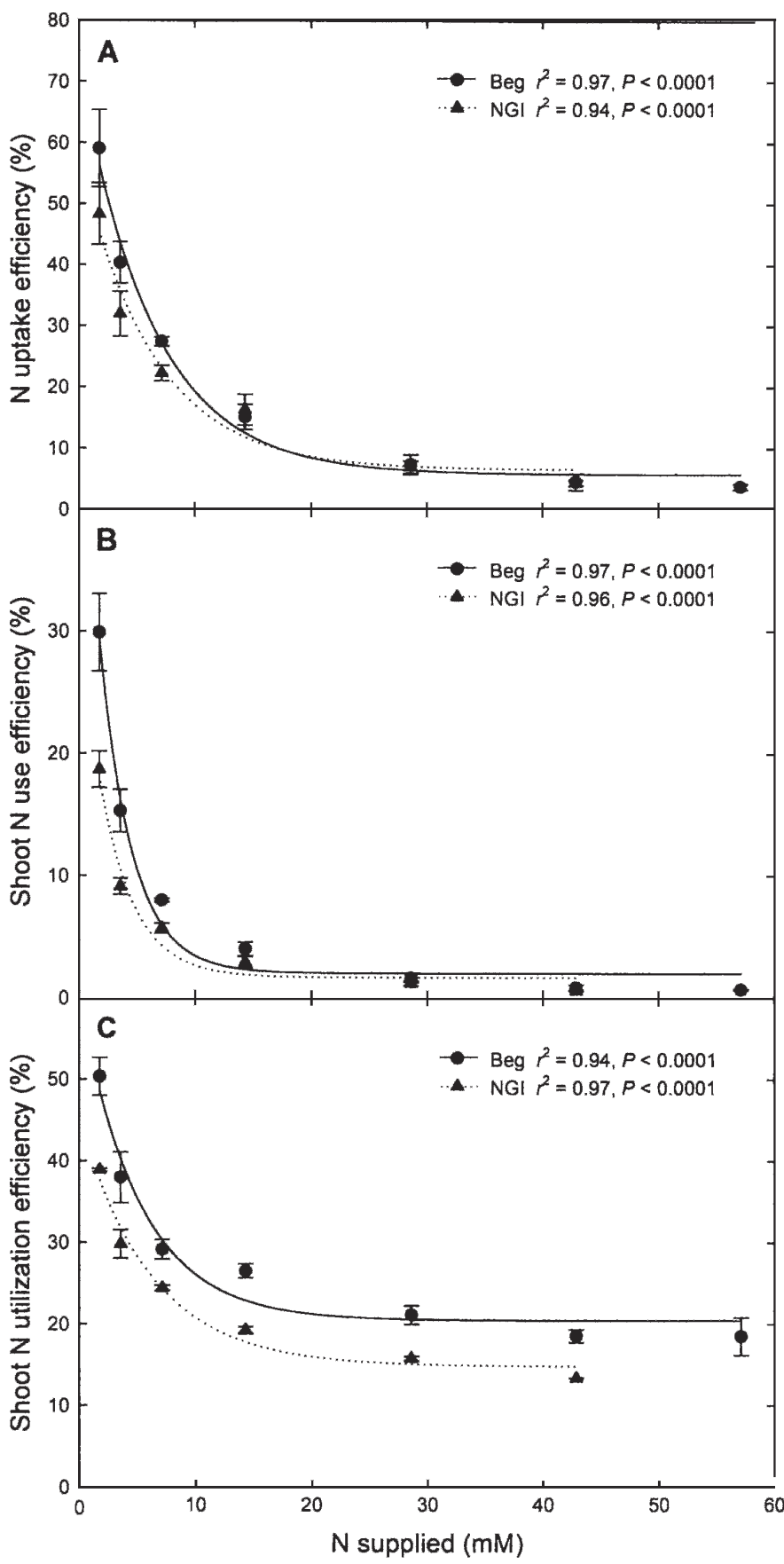

Fig. 8. Nitrogen efficiency parameters are influenced by $\mathrm{N}$ supply in begonia (Beg) and new guinea impatiens (NGI). N uptake efficiency (A) (tissue $\mathrm{N}$ concentration $\times$ shoot dry weight/ $\mathrm{N}$ supply) in Beg $\mathrm{n}=44 ; \mathrm{y}=5.76+$ $67.61 \mathrm{e}(-0.16 \mathrm{x})$ and in NGI $\mathrm{n}=17 ; \mathrm{y}=6.56+51.85 \mathrm{e}(-0.16 \mathrm{x})$, shoot $\mathrm{N}$ use efficiency $(B)($ shoot dry weight/ $\mathrm{N}$ supply $\times 100)$ in Beg $n=44 ; y=2.02+$ $52.30 \mathrm{e}(-0.36 \mathrm{x})$, and in NGI $\mathrm{n}=17 ; \mathrm{y}=1.67+30.54 \mathrm{e}(-0.35 \mathrm{x})$, shoot $\mathrm{N}$ utilization $(\mathbf{C})($ shoot dry weight/total $\mathrm{N}$ content $\times 100)$ in Beg $\mathrm{n}=44 ; \mathrm{y}=$ $20.46+39.89 \mathrm{e}(-0.20 \mathrm{x})$, and in NGI $\mathrm{n}=17 ; \mathrm{y}=14.82+30.43 \mathrm{e}(-0.16 \mathrm{x})$. $r^{2}$ values are presented when it is statistically significant at $P<0.0001$. Error bars are \pm 1 standard deviation from the average.

$\mathrm{N}$ uptake efficiency decreased with increasing $\mathrm{N}$ supply (Fig. 8). In a supraoptimal $\mathrm{N}$ environment, the additional $\mathrm{C}$ needed for amino acid synthesis was likely provided at the expense of biomass synthesis (Champigny, 1995). This shift in carbon partitioning may result in $\mathrm{N}$ within the tissue not being assimilated because the $\mathrm{N}$ uptake mechanism remains efficient, whereas dry matter gain is less efficient. The linear increase in energy per gram of tissues from plants supplied with elevated $\mathrm{N}$ rate (Fig. 7) may have contributed to the corresponding high infection rate of $B$. cinerea in Beg.

$\mathrm{N}$ use efficiency declined significantly with increasing $\mathrm{N}$ supply (Fig. 8). Higher levels of $\mathrm{N}$ increased tissue caloric value and altered leaf orientation, which correlated with greater disease incidence. $\mathrm{N}$ supply between the ranges of 3.57 and 14.3 $\mathrm{mm}$ was found to be optimal for plant growth and development in Beg and NGI based on appearance, growth, and development and susceptibility to $B$. cinerea infection. These amounts differ from amounts commonly applied in commercial greenhouses of at least $14.3 \mathrm{~mm} \mathrm{~N}$ with periodic fertigation double or triple that amount. Additional studies on $\mathrm{N}$ form and concentration and interaction of environmental factors with species that are sensitive to both extremes of $\mathrm{N}$ form will generate more information for $\mathrm{N}$ use efficiency. Additional tests should be done to determine the direct versus indirect effects of elevated $\mathrm{N}$ on floricultural crops to see if elevated $\mathrm{N}$ primarily caused the growth effects and increased susceptibility or the resulting stresses from altered $\mathrm{pH}$ and EC caused the observed effects. Regardless of the specific causes, elevated yet sublethal $\mathrm{N}$ levels can lead to significant growth effects on these floricultural crops.

\section{Literature Cited}

Britto, D.T. and H.J. Kronzucker. 2005. Nitrogen acquisition, PEP carboxylase, and cellular $\mathrm{pH}$ homeostasis: New views on old paradigms. Plant Cell Environ. 28:1396-1409.

Britto, D.T., M.Y. Siddiqui, A.D.M. Glass, and H.J. Kronzucker. 2001a. Futile transmembrane $\mathrm{NH}_{4}{ }^{+}$cycling: A cellular hypothesis to explain ammonium toxicity in plants. Proc. Natl. Acad. Sci. USA 98:4255-4258.

Britto, D.T., A.D.M. Glass, H.J. Kronzucker, and M.Y. Siddiqui. 2001b. Cytosolic concentrations and transmembrane fluxes of $\mathrm{NH}_{4}{ }^{+}$/ $\mathrm{NH}_{3}$ : An examination of recent proposals. Plant Physiol. 125: 523-526.

Champigny, M.L. 1995. Integration of photosynthetic carbon and nitrogen metabolism in higher plants. Photosyn. Res. 46:117-127.

David, M., J. Swiader, K. Williams, and D. Eastburn. 2003. Nitrogen nutrition, but not potassium, affects powdery mildew development in hiemalis begonia. J. Plant Nutr. 26:159-176.

Díaz-Pérez, J.C., A.C. Purvis, and J.T. Paulk. 2003. Bolting, yield, and bulb decay of sweet onion as affected by nitrogen fertilization. J. Amer. Soc. Hort. Sci. 128:144-149.

Elad, Y. 1988. Involvement of ethylene in the disease caused by Botrytis cinerea on rose and carnation flowers and the possibility of control. J. Appl. Bot. 113:589-598.

Elad, Y. and K. Evensen. 1995. Physiological aspects of resistance to Botrytis cinerea. Phytopathology 85:637-643.

Elad, Y. and D. Shtienberg. 1995. Botrytis cinerea in greenhouse vegetables: Chemical, cultural, physiological and biological controls and their integration. Integrated Pest Mgt. Rev. 1:15-29.

Elad, Y. and H. Volpin. 1993. Reduced sensitivity to gray mould (Botrytis cinerea) of bean and tomato plants by means of calcium nutrition. J. Phytopathol. 139:146-156.

Engelhard, A.W. 1989. Management of diseases with macro- and microelements. 1st ed. APS Press, St. Paul, Minn.

Epstein, E. and A.J. Bloom. 2005. Mineral nutrition of plants: Principles and perspectives. 2nd ed. Sinauer Associates, Sunderland, Mass.

Goins, G.D., N.C. Yorio, and R.M. Wheeler. 2004. Influence of nitrogen nutrition management on biomass partitioning and nitrogen 
use efficiency indices in hydroponically grown potato. J. Amer. Soc. Hort. Sci. 129:134-140.

Good, A.G., A.K. Shrawat, and D.G. Muench. 2004. Can less yield more? Is reducing nutrient input into the environment compatible with maintaining crop production? Trends Plant Sci. 9:1360-1385.

Hamlin, R.L., H.A. Mills, and W.M. Randle. 1999. Growth and nutrition of pansy as influenced by $\mathrm{N}$-form ratio and temperature. J. Plant Nutr. 22:1637-1650.

Harris, C.E., E.H. Simonne, and D.J. Eakes. 1999. Effect of nitrogen form ratio on pansy growth and nutrition and the palatability to white-tailed deer. J. Plant Nutr. 22:1807-1814.

Harrison, J.G. 1988. The biology of Botrytis spp. on Vicia beans and chocolate spot disease-A review. Plant Pathol. 37:168-201.

Hartley, D.E. 1995. Feeding and watering, p. 31-39. In: W. Banner and M. Klopmeyer (eds.). New guinea impatiens: A Ball guide. Ball Publishing, Batavia, Ill.

Hausbeck, M.K. and G.W. Moorman. 1996. Managing Botrytis in greenhouse-grown flower crops. Plant Dis. 80:1212-1219.

Hoffland, E., M.J. Jeger, and M.L. van Beusichem. 2000. Effect of nitrogen supply rate on disease resistance in tomato depends on the pathogen. Plant Soil 218:239-247.

Hoffland, E., M.L. van Beusichem, and M.J. Jeger. 1999. Nitrogen availability and susceptibility of tomato leaves to Botrytis cinerea. Plant Soil 210:263-272.

Huber, D.M. and R.D. Watson. 1974. Nitrogen form and plant disease. Annu. Rev. Phytopathol. 12:139-165.

Jarvis, W.R. 1992. Managing diseases in greenhouse crops. 1st ed. APS Press, St. Paul, Minn.

Kent, M.W. and D.W. Reed. 1996. Nitrogen nutrition of new guinea impatiens 'Barbados' and Spathiphyllum 'Petite' in a subirrigation system. J. Amer. Soc. Hort. Sci. 121:816-819.

Kirby, E.A. and K. Mengel. 1967. Ionic balance in different tissues of tomato plants in relation to nitrate, urea and ammonium nutrition. Plant Physiol. 42:6-14.

Long, F. 1934. Application of calorimetric methods to ecological research. Plant Physiol. 9:323-337.

Magalhaes, J.R. and D.M. Huber. 1989. Ammonium assimilation in different plant species as affected by nitrogen form and $\mathrm{pH}$ control in solution culture. Fert. Res. 21:1-6.

Mansfield, J.W. 1980. Mechanisms of resistance to Botytis, p. 181218. In: J.R. Coley-mith, K. Verhoeff, and W.R. Jarvis (eds.). The biology of Botrytis. Academic Press, London.

Marshner, H. 1995. Mineral nutrition of higher plants. 2nd ed. Academic Press, N.Y.

Mengel, K. and E.A. Kirby. 2001. Principles of plant nutrition. 5th ed. Kluwer Academic Publishers, London.

Mills, H.A. and B. Jones, Jr. 1996. Plant analysis handbook II: A practical sampling, preparation, analysis, and interpretation guide. MicroMacro Publishing, Athens, Ga.
Nelson, P.V. 1996. Macronutrient fertilizer programs, p. 141-170. In: D.W. Reed (ed.). Water, media, and nutrition for greenhouse crops. Ball Publishing, Batavia, Ill.

Nelson, P.V. 2005. Greenhouse management and operation. 6th ed. Prentice-Hall, N.Y.

Nelson, P.V., D.M. Krauskopf, and N.C. Mingis. 1978. Nitrogen and potassium requirements of Reiger begonia (Begonia hiemalis Fotsch). J. Amer. Soc. Hort. Sci. 103:603-605.

Osorio, N.W., X. Shuai, S. Miyasaka, B. Wang, R.L. Shirley, and W.J. Wigmore. 2003. Nitrogen level and form affect taro growth and nutrition. HortScience 38:36-40.

Pitchay, D.S. 2002. Impact of 11 elemental nutrient deficiencies on shoot and root growth, and foliar analysis standards of 13 ornamental taxa with emphasis on $\mathrm{Ca}$ and $\mathrm{B}$ control of root apical meristem development. N.C. State Univ., Raleigh. PhD Diss.

Powell, C.L., K.I. Caldwell, R.A. Littler, and I. Warrington. 1988. Effect of temperature regime and nitrogen fertilizer level on vegetative and reproductive bud development in Cymbidium orchids. J. Amer. Soc. Hort. Sci. 113:552-556.

Smith, M.A., G.C. Elliott, and M.P. Bridgen. 1998. Calcium and nitrogen fertilization of Alstroemeria for cut flower production. HortScience 33:55-59.

Sprague, H.B. 1964. Hunger signs in crops. 3rd ed. David McKay, N.Y. Stall, R.E. 1963. Effects of lime on Botrytis gray mold of tomato. Phytopathology 53:149-151.

Talbot, L.D. and E. Zeiger. 1996. Role of potassium and sucrose in guard-cell osmoregulation. Plant Physiol. 111:1051-1057.

Townsend, B.B. 1957. Nutritional factors influencing the production of sclerotia by certain fungi. Ann. Bot. (Lond.) 21:153-166.

U.S. Dept. Agr. 2005. Floriculture crops 2004 summary. Natl. Agr. Stat. Serv., Washington, D.C.

van Beusichem, M.L., E.A. Kirby, and R. Baas. 1988. Influence of nitrate and ammonium nutrition on the uptake, assimilation, and distribution of nutrients in Ricinus communis. Plant Physiol. 86:914921.

van Kan, J.A.L. 2005. Infection strategies of Botrytis cinerea. Acta Hort. 669:77-89.

Volpin, H. and Y. Elad. 1991. Influence of calcium nutrition on susceptibility of rose flowers to Botrytis blight. Phytopathology 81:1390-1394.

von Wiren, N., S. Gazzarrini, A. Gojon, and W.B. Frommer. 2000. The molecular physiology of ammonium uptake and retrieval. Curr. Opin. Plant Biol. 3:254-261.

Wright, R.D. 1986. The pour-through nutrient extraction procedure. HortScience 21:227-229.

Yang, J., B. Weske, C. Jie, and J. Nin. 2003. Quantitative caloric energy distribution and variations in two rice varieties related to different nitrogen application levels in paddy field. J. Plant Nutr. 26:709-729. 